University of Windsor

Scholarship at UWindsor

OSSA Conference Archive

OSSA 6

Jun 1st, 9:00 AM - 5:00 PM

Dialectical Soundness of Dissociation

M A. van Rees

Universiteit van Amsterdam

Follow this and additional works at: https://scholar.uwindsor.ca/ossaarchive

van Rees, M A., "Dialectical Soundness of Dissociation" (2005). OSSA Conference Archive. 46.

https://scholar.uwindsor.ca/ossaarchive/OSSA6/papers/46

This Restricted Access is brought to you for free and open access by the Conferences and Conference Proceedings at Scholarship at UWindsor. It has been accepted for inclusion in OSSA Conference Archive by an authorized conference organizer of Scholarship at UWindsor. For more information, please contact scholarship@uwindsor.ca. 


\title{
Dialectical Soundness of Dissociation
}

\author{
M.A. VAN REES \\ Leerstoelgroep Taalbeheersing, Argumentatietheorie en Retorica \\ Universiteit van Amsterdam \\ Spuistraat 134 \\ 1012 VB Amsterdam \\ The Netherlands \\ m.a.vanrees@uva.nl
}

\begin{abstract}
In this paper, I investigate under what circumstances the use of the argumentative technique of dissociation can be judged dialectically sound. The perspective from which this question is approached is that of pragma-dialectics. Because, in pragma-dialectics, the rules for critical discussion concern the performance of speech acts in the various stages of a critical discussion, I consider, first, after a short introduction on dissociation, what speech acts are involved in this argumentative technique, and how these speech acts are performed. Then, I delineate the conditions under which the performance of these speech acts can be considered dialectically sound, in the light of the rules for critical discussion. I distinguish procedural and material requirements for dialectical soundness of dissociation. For each of these, I stipulate the criteria for determining whether the requirements have been met. These criteria are derived from the earlier discussion of the ways in which the speech acts involved in dissociation can be performed and from the general and specific purposes of these speech acts in their use in dissociation.
\end{abstract}

KEY WORDS: dissociation, definition, distinction, critical discussion

\section{INTRODUCTION}

Dissociation is one of the two types of argument scheme distinguished by Perelman and Olbrechts-Tyteca in their influential treatise of argumentative techniques The New Rhetoric. In a dissociation, the speaker splits up a notion considered by the audience to form a unitary concept into two new concepts, each comprising only part of the original notion. A wellknown example is the dissociation of the single concept of law into two new concepts, the letter of the law and the spirit of the law.

The result of a dissociation is that a statement containing the original concept in one of the reduced versions can be denied, while at the same time a statement with the original concept in the other reduced version can be asserted, without the speaker running into a contradiction. A juridical decision, for example, can be called, without contradiction, both in accordance with the letter and in opposition to the spirit of the law.

Dissociation is an argumentative technique. Its argumentative potential is based on the fact that the two concepts resulting from the separation of the original notion are portrayed as non-equivalent: the one is represented as more important or more essential than the other. Thus, it depends on which of the two, the spirit or the letter of the law, is represented as decisive, whether the juridical decision from the previous example can be considered to be justified or not.

Dissociation can have different consequences for the use of the term that stood for the original unitary concept. Firstly, the term can be abandoned; for the two split-off concepts two new terms are introduced. That is the case with the dissociation of the original term 'law', which is replaced by two new terms, 'the letter of the law' and 'the spirit of the law'. Secondly, the term that stood for the original unitary concept can be kept, now denoting a reduced concept, while for the concept that has been split off a new term is introduced. An 
example is the dissociation of the original term 'dead', in which the term 'brain dead' is introduced for the split-off concept 'showing no brain activity', while the meaning of the original term is reduced to 'showing no outward signs of life'.

In earlier work, I have concentrated on the dialectical contexts in which dissociation can be used and the ways in which it becomes manifest in these contexts (van Rees, 2002, 2003). I have shown that dissociation can be used in diverse ways in the various stages of a critical discussion, with varying dialectical and rhetorical effects. In the present paper, I endeavour to answer the question under what circumstances these various uses of dissociation can be judged dialectically sound. ${ }^{1}$ Because the rules for critical discussion concern the performance of speech acts in the various stages of a critical discussion, first, in section 2, I investigate what speech acts are involved in dissociation. Section 3 is dedicated to the main question: when dissociation may be judged dialectically sound. Using a distinction that van Eemeren \& Houtlosser (2002a) introduce between procedural and material premises, I discuss procedural (3.1) and material (3.2) requirements for dialectical soundness of dissociation. In the conclusion, I summarize my findings.

\section{SPEECH ACTS IN DISSOCIATION}

Dissociation implies that a unitary concept expressed by a single term is split up into two new concepts, one subsumed under a new term, the other subsumed either under the original term which is redefined to denote a concept reduced in content, or under another new term with its own definition, the original term being given up altogether. This means that in a dissociation two speech acts are performed: distinction and definition. Both speech acts belong to the socalled usage declaratives (van Eemeren \& Grootendorst, 1984), speech acts that are aimed at clarifying linguistic usage.

The two speech acts inherent in dissociation can be performed recognizably as such in various degrees. Like all speech acts, they can be performed explicitly, implicitly, or indirectly, but in dissociation they are often not performed at all, but merely presupposed.

Explicit performance takes place through the use of a performative formula, as in the definition in the following example: ${ }^{2}$

(1) In this light I define 'the original meaning' of a text as: 'what it says in the text in the light of the information that we have about the time of its origin'. This definition implies that the original meaning of a text is not a characteristic of the text, but the result of a purposeful approach to the text by the reader, the reconstruction of the meaning of the text at the time of its origin. A historical interpretation of a text thus is not the retrieval of the one and only correct original meaning of the text, but the critical consideration of the current interpretations of a text by means of the information we have about the time of its origin.

www.library.uu.nl/digiarchief/dip/diss/2004-0205-103455/sam.pdf, p.2

By means of the performative formula 'I define' a (re-) definition of the term 'original meaning' is performed, bringing about a dissociation between the historical interpretation of a text and the one and only correct meaning inherent in the text.

An example of explicit performance of a distinction is provided by the following text:

\footnotetext{
${ }^{1}$ Thanking Frans van Eemeren, Peter Houtlosser and Francisca Snoeck Henkemans, whose critical comments on earlier versions of this paper helped considerably in clearing my mind.

${ }^{2}$ All examples have been translated from Dutch.
} 
Q: Is the striving for a decent society not just as unattainable as the striving for a just society?

A: I don't think so. I make a distinction between a decent and a civilized society. In a civilized society nobody humiliates anybody. Sure enough, that is ambitious. But for a decent society, what matters are the social institutions. Those you can require not to humiliate people.

Een rechtvaardige vrede is een ramp (http://www.j-accuse.nl/index.html)

By means of the performative formula 'I make a distinction' a dissociative distinction is introduced between a decent and a civilized society.

Implicit performance occurs when no performative formula is present, but the expressions that are used have syntactic and semantic characteristics that make them preeminently fit for performing the speech act that is intended. An example can be found in the following commentary on certain irregularities that were found in the judgment of some of the Olympic winter games in 2002:
Jury sports must go back to the circus, ice show, or freak show. Everything is all right, as long as we are delivered from them during the real sports events. Sports are sports except jury sports, another word for unfair. Jury sports are sometimes quite nice to watch, but they shouldn't be made into competitive games.

De Volkskrant 15-02-2002

In 'Sports are sports, except jury sports', a (circular) definition of 'sports' is given, bringing about a dissociation between sports and jury sports.

An example of implicit performance of a distinction can be found in the following passage from an argument against the idea that shared nationality implies shared values:

To be sure, in the debate about immigrants invariably 'the Dutchman' emerges as a mythical hero, an indestructible unity of nationality and indigenous culture. But that unity is not so indestructible, so indivisible (...).

It is strange that in the debate about multiculturality so little attention is given to the meaning of being Dutch. (...)We should precizate the image of the Dutchman: there is a difference between our cultural and our constitutional nationality.

De Volkskrant 16-03-2002

By means of 'there is a difference between', a dissociative distinction between cultural and constitutional nationality is made.

Indirect performance of a speech act occurs when the expressions used have syntactic and semantic characteristics that make them pre-eminently fit for performing another speech act than the one intended (van Rees, 1982). An example can be found in the following text:

\footnotetext{
Therefore, we must define growth and shrinkage differently: the Gross National Product now is a sum of economic activities, some of which enhance, but others of which harm our welfare (for instance pollution). Growth must be defined as growth of welfare, care, services, et cetera.
}

www.globalternatives.nl/file/147

The assertion that it is necessary to perform a speech act, as in 'we must define' and 'must be defined', is a conventional way of performing that speech act indirectly (Searle, 1975). In this example, the indirectly performed definition brings about a dissociation between growth of all economic activities and growth of beneficial activities.

An example of indirect performance of a dissociative distinction is provided by the following text: 
a divorce. A couple of days later he discovers that everybody in his church knows about it. He approaches his minister. But the minister says he sees no problem. Brothers and sisters need to know these things in order to be able to forgive them. Even though the minister has been consistent in passing on the information, we would not call him honest.

http://www.bezinningscentrum.nl/teksten/bert/inleidinintegriteit.htm

By means of 'I have to introduce a second distinction', indirectly a dissociative distinction is made between formal and material honesty.

Apart from the cases just considered, in which the definition or the distinction is explicitly, implicitly, or indirectly performed, there also are cases in which the speech act is not performed, but presupposed. An example can be found in former Minister Jorritsma's defense of once again tolerating a violation of the allowable noise levels for Schiphol airport: According to Jorritsma, the cabinet will not revert to a tolerance policy, such as was applied in 1997.
'That was once, but never again, we said at the time. But tolerating is something quite different from
anticipating on a change of law which everybody thinks should be put into effect'.

De Volkskrant 22-01-1998

Jorritsma presupposes that two concepts can be distinguished, 'tolerating', and 'anticipating on a change of law which everybody thinks should be put into effect', and asserts that the one is something quite different from the other. The presupposed distinction also entails a presupposed redefinition of 'tolerating' in which the meaning of this term is reduced to allowing the violation of legal regulations without anticipation on a change of law.

The distinction is also presupposed when an entity is simply classified in one of two categories that as such are taken for granted. An example is provided by the following passage in which the granddaughter of Maria Montessori defends her grandmother against some of her critics:

That her grandmother is known for being ambitious and vain, she also deems irrelevant. And incorrect, as well. 'She loved beautiful clothes, but was not vain'.

De Volkskrant 5-1-1999

In this example, Maria Montessori is classified as belonging to the class of people who love beautiful clothes, rather than the category of people who are vain. This is done on the basis of a presupposed distinction between these two categories, also entailing a presupposed redefinition of the term 'vain' in which this term is deemed applicable only to the mental aspects of this concept. ${ }^{3}$

Whether performed or presupposed, the usage declaratives involved in dissociation create new usage. The distinction is newly made: previous to the dissociation, there was just the unitary concept. And the original term is either replaced by two new terms, each with its own definition, or by a new term and the original term with a new definition, comprising a reduction in content.

\section{SOUNDNESS OF DISSOCIATION}

From a pragma-dialectical perspective, the fact that in a dissociation a new, previously not made distinction is created within a unitary concept, and an existing definition of a term is replaced by a new one, means that one of the starting points of a critical discussion is

\footnotetext{
${ }^{3}$ Sometimes the presupposed definition intended by the speaker even cannot be retrieved. Zarefsky et al. analyze an example of this in a speech of former US president Ronald Reagan, in which he proposes a safety net for the 'truly needy', without it being clear what the criterion for poverty might be.
} 
changed. An agreement made by protagonist and antagonist in the opening stage of a critical discussion about the content of a concept and the meaning of a term is modified.

According to the ideal model of critical discussion, a consequence of a change in the agreements that have been reached in the opening stage of the discussion is that a sidediscussion must be held about the acceptability of this change, before the main discussion can be pursued. In this side-discussion, the speaker who introduces the dissociation makes a proposal for changing the starting point in question. If the antagonist does not accept this proposal, the protagonist must either withdraw or defend it. ${ }^{4}$ The dissociation may be maintained in the main discussion only if the side-discussion results in the antagonist's accepting the change in the starting points effectuated by the dissociation. If the antagonist does not accept this change, and the protagonist nevertheless uses the dissociation in the main discussion as if the modified content of the concept used and the modified meaning of the term used belong to the agreed-upon starting points of the discussion, the protagonist in the main discussion commits a violation of the starting-point rule of a critical discussion: discussants may not falsely present something as an accepted starting point (van Eemeren \& Grootendorst, 2004, p. 193). ${ }^{5}$ If the protagonist puts the change up for discussion, however, and the result of that discussion is that the antagonist accepts it, the protagonist can use the dissociation in the main discussion without violating the starting-point rule. When these two conditions are fulfilled, the dissociation is dialectically sound.

The two conditions just mentioned represent the two kinds of requirement for dialectical soundness of dissociation, which, following van Eemeren \& Houtlosser's distinction between procedural and material premises (2002a, p. 20), I shall name procedural and material requirements. If the protagonist puts the change in starting points up for discussion, the procedural requirements have been met. If, in the side-discussion, the antagonist accepts the change, the material requirements have been met. In a dissociation that is dialectically sound, both kinds of requirement have been met.

\subsection{Procedural requirements}

Only if the protagonist follows the procedure for conducting a critical discussion by putting the change in starting points implied by a dissociation up for discussion, the dissociation meets the procedural requirements for dialectical soundness. The protagonist can do so in two ways. In the first place, he can present the change in starting points as a standpoint, by recognizably performing the speech act of creating a distinction or introducing a definition. By recognizably creating a distinction that did not exist before, or introducing a definition that is new, the speaker places the acceptability of these speech acts at issue, thereby giving them the status of a standpoint. In the second place, the protagonist can bring forward argumentation in favor of the change in starting points that the dissociation entails. Even if he did not present it as a standpoint to begin with, through advancing argumentation he makes it into a standpoint after all.

Looking back to the account in section 2 of this paper of the various ways in which making a distinction or introducing a definition can be performed, we can conclude that, by virtue of the rules and conventions for the performance of speech acts, these speech acts are performed recognizably if they are performed explicitly, implicitly or indirectly. That is not the case when they are not performed but presupposed, as in examples (7) and (8). In that case, the acceptability of the distinction or definition as such is not put up for discussion. So,

\footnotetext{
${ }^{4}$ See van Eemeren, Houtlosser \& Snoeck Henkemans (2005) for the dialectical profile of a discussion in the opening stage of a critical discussion.

${ }^{5}$ Grootendorst (1999), also, considers the case he analyzes as a 'fallacy of incorrect dissociation' to constitute a violation of this rule.
} 
when the distinction or the definition is merely presupposed, the dissociation does not meet the procedural requirements for dialectical soundness.

A clear indication that we are dealing with procedurally unsound dissociation is provided in those cases in which the protagonist emphasizes that the change in conceptual content or meaning needs no further discussion by textually indicating that it is a matter of fact. That is what happens, for example, in the following passage from a report of a juridical feud between Eurocommissar Bolkestein and TV-presenter Fons de Poel. The politician had accused the journalist of having filed a false declaration with the IRS.

Bolkestein earlier did place a rectification in $V N$. In this, he says: 'I meant 'fraudulent declaration' not in the technical sense of the word, but in the sense of cooperating in giving a patently false impression of things with regard to my tax declaration'.

De Volkskrant 13-11-1999

Bolkestein in his rectification presupposes that the term 'false declaration' has two meanings (one of which, by the way, is quite new). Through the existential presupposition that is connected with the use of the definite article in the expression 'in the sense of', this definition is presented as an uncontested fact.

The following example, likewise, provides an instance of this kind of factual presentation. The author jumps to the defense of the main sponsor of the Dutch skating team that congratulated the skaters in an advertisement on their victory, even though during the Olympic games sponsors are not allowed to mention their sponsorship in their ads.

(10) The insurance company is a solid sponsor that has been financially supporting skating as a sport for a quarter of a century. (...) Apparently Blankert doesn't recognize the difference between bona-fide financiers that have built sports and opportunist sponsors.

Algemeen Dagblad 19-02-2002

Through the existential presupposition connected with the use of the definite article in 'the difference', the distinction between sponsors and spurious sponsors is presented as a matter of fact, as is the redefinition of the word 'sponsor' in which the meaning of this term is limited to a person or organization that lends financial support during an extended period.

If the change in starting points is not put up for discussion through the recognizable performance of one of the speech acts that bring it about, it can be made into a standpoint after all through advancing argumentation in favor of it. In the examples above this was not the case. In following example, it is:

(11) The discomfort at cloning of humans seems to me to be the product of confusion between the notions 'identical people' and 'genetically identical people'. When you have two genetically identical flower bulbs, you can exchange the one for the other without any problem: genetically identical for bulbs means identical. In other words: the value of an individual bulb decreases, the more genetically identical ones there are. One black tulip is very special. But if the Keukenhof is full of them, no tourist will come and look at them.

But people are not bulbs. The value and dignity of people is not determined by their genetic make-up, but by the fact of them being humans. Or are identical twins (a 'natural' clone!) worth less than two 'ordinary' brothers? Someone married to half of a twin wouldn't want to exchange the one for the other, would they?

There is a simple reason for that: 'genetically identical' in humans is something quite different from 'identical'. Individuality does not reside in the genes.

That is why humanity or human dignity is not threatened by cloning as such. That only happens if we start to value people differently on the basis of their genes. As happens now, already as well, by the way, under the name of 'racism'.

De Volkskrant 11-04-1997 
The speaker quoted in this interview presupposes a distinction between identical and genetically identical ("'genetically identical' in humans is something quite different from 'identical"'). Through adducing arguments for the necessity of this distinction, however, he puts it up for discussion, after all.

\subsection{Material requirements}

Not only must the change in starting points of the discussion inherent in a dissociation be put up for discussion by the protagonist, it also must be accepted by the antagonist. If the latter is not the case, the dissociation does not meet the material requirements for dialectical soundness.

Although in principle discussants are free to decide on the list of mutually accepted starting points (van Eemeren \& Grootendorst, 2004, p. 149), we can delineate two general criteria on the basis of which the antagonist can decide on the acceptability of the new distinction or redefinition introduced by a dissociation. These criteria relate, respectively, to the general and the specific aims that are associated with the speech acts performed in the dissociation. The general aim of usage declaratives, the type of speech acts that definition and distinction belong to, is to bring about discursive and conceptual clarification and to solve demarcation problems (van Eemeren \& Grootendorst, 1984; Viskil, 1994). The specific aim of the usage declaratives inherent in dissociation is to resolve a contradiction. I begin with the latter.

Dissociation serves to resolve a contradiction because through a dissociation the speaker, within a notion that was until then considered a conceptual unity, makes a distinction between term I and term II, which allows him to maintain, without contradicting himself, that a proposition containing term I or derived from a proposition containing term I is tenable and a proposition containing term II or derived from a proposition containing term II is not. Thus Jorritsma, in example (7), may maintain, without contradicting herself, that she does allow a violation of legal regulations, but does not carry out a tolerance policy; Bolkestein, in example (9), may maintain that De Poel has filed a fraudulent declaration, and at the same time claim that he has not, in the technical sense; and Maria Montessori's granddaughter, in example (8), may maintain that her grandmother was not vain, and at the same time assert that she was, in the physical sense.

Given this specific aim of the speech acts inherent in dissociation, it is of crucial importance that the antagonist is of the opinion that in actual fact a distinction can be made between term I and term II. If the antagonist feels that the distinction between the two concepts is merely verbal and does not exist in reality, or if he believes that the meaning of the two terms in actual fact is identical, the contradiction cannot be resolved by the dissociation. This, then, is the first of the general criteria on the basis of which an antagonist may deem the change in starting points brought about by a dissociation not acceptable.

Dissociation being an argumentative technique, there is a specific way in which the above criterion may not be met, which occurs when the new term denoting a concept differs from the old one merely in emotive meaning, not in connotation (or intension). That is the basis on which, for instance, an antagonist might reject the dissociation in example (7). He might object that anticipating on a change of law which everybody thinks should be put into effect in actual fact is exactly the same as tolerating, namely allowing something that is prohibited by the existing legal regulations, the only difference being that the former expression has a positive emotive meaning, and the latter a negative one.

On the same grounds an antagonist might consider the distinction in the following example unacceptable. A shopkeeper, to fight shoplifting, had a cell built in his shop. The 
question is whether this causes him to commit an offence. A spokesman for the Attorney General asserts that no action will be taken against him:

(12) 'The only thing is, he may not lock anyone up without the police knowing about it, and he may not call it a cell. We view it as a detainment room'.

NRC/Handelsblad 20-03-2003

An antagonist might object that a cell and a detainment room are one and the same thing, both serving to lock someone up, the latter term being a mere euphemism for the former. ${ }^{6}$

The distinction and definition inherent in dissociation must be functional not just in view of the aims of these speech acts that are specific for dissociation, they must also be so in view of the general aims of these speech acts: they must contribute to the clarity of discourse and to the resolution of demarcation problems. That means that they must have a point outside the specific purpose of the speaker to escape from a particular contradiction in the discussion; that is, they should be used not merely ad hoc. Given this general aim of the speech acts inherent in dissociation, it is of crucial importance that the antagonist is of the opinion that the distinction or the definition has some use outside of resolving the particular contradiction for the resolution of which it has been introduced. This, then, is the second of the general criteria on the basis of which an antagonist may deem the change in starting points brought about by a dissociation not acceptable.

On the basis of this second criterion an antagonist might consider the dissociation in example (9), for instance, unacceptable: within the framework of tax legislation it is conceivably quite impracticable to depart from the usual terminology (according to which filing a declaration with the IRS is something quite different from cooperating in giving a patently false impression of things, and a fraudulent declaration concerns one's own tax, not that of someone else).

On the same grounds, an antagonist might consider the dissociation in the next conversational fragment unacceptable:
A: $\quad$ he is a good manager
B: $\quad$ well, he certainly couldn't prevent that subsidy cut-off
A: yes, he isn't a good crisis manager, but as a general manager he's just fine

Speaker A limits the meaning of the word 'manager' to an executive from whom it cannot be expected to manifest good leadership in times of crisis, an unusual and conceivably impracticable limitation for appointing managers. A similar limitation, raising similar doubts with respect to its viability, occurs in example (8), in which the meaning of the word 'sponsor' is limited such that a person or organization lending financial support for a short period in time may not be called a sponsor.

\section{CONCLUSION}

In this paper, I have tried to answer the question when the use of a dissociation may be considered dialectically sound. First, I showed that in a dissociation two speech acts are performed, making a distinction and introducing a definition, that bring about a change in the starting points for the discussion. These speech acts can be performed recognizably in various degrees.

\footnotetext{
${ }^{6}$ Within the institutional context of the law, however, this distinction may be acceptable.
} 
The fact that the speech acts performed in a dissociation bring about a change in the starting points for the discussion, means, from the perspective of the rules for critical discussion, that, first, a side-discussion must be started that must result in the antagonist's acceptance of this change, in order for the dissociation to be able to be sustained in the main discussion. If this side-discussion is not started, or if it is, but the antagonist does not accept the change in starting points, and the protagonist nevertheless uses the dissociation in the main discussion as if the change in the concept or the meaning of the term used belongs to the mutually accepted starting points of the discussion, the protagonist in the main discussion commits a violation of rule 6 for critical discussion: discussants may not falsely present something as an accepted starting point.

From this general characterization two kinds of requirement for the dialectical soundness of dissociation can be derived, procedural and material. The former are not met when no side-discussion about the acceptability of the change in starting points is started; the latter, when the antagonist in the side-discussion does not find that change acceptable.

The procedural requirements are met when the change in the starting points for the discussion is put up for discussion, either by way of presenting it as a standpoint, or by way of advancing arguments for it. The former occurs if the speech acts that are inherent in dissociation are performed recognizably. If these speech acts are not performed explicitly, implicitly, or indirectly, but are presupposed, and no argumentation for their acceptability is supplied, the procedural requirements for dialectical soundness are not met.

The material requirements are met when the antagonist in the side-discussion accepts the change in starting points for the discussion. The criteria on the basis of which the antagonist may judge the acceptability of the change can be derived from the general and specific aims that are associated with the speech acts that are inherent in dissociation, respectively, discursive and conceptual clarification, and resolution of a contradiction. If the distinction between the two terms is not tenable in the eyes of the antagonist, the latter kind of aim cannot be attained; if the distinction made or definition introduced is merely ad hoc in the eyes of the antagonist, the former kind of aim cannot be attained.

Dissociation is a powerful instrument to clarify discussions and to structure our conception of reality. The speech acts of distinction and definition that are inherent in dissociation have a clarifying function and can play an important role in opening the way to new possibilities of thought (Naess, 1966). This functionality of dissociation is the banner of reasonableness under which this argumentative technique can be used as a way of maneuvering strategically in the various stages of a critical discussion (van Eemeren \& Houtlosser, 2002b). Those maneuvers are in no way by definition dialectically unsound. Problems arise only when a dissociation is used while the definition or the distinction inherent in it is not put up for discussion but presented as given, or when the antagonist does not accept the change in the mutually accepted starting points that these speech acts bring about.

\section{REFERENCES}

Eemeren, Frans H. van \& Rob Grootendorst: 1984, Speech Acts in Argumentative Discussions. Dordrecht: Foris. Eemeren, Frans H. van \& Rob Grootendorst: 2004, A Systematic Theory of Argumentation. The pragmadialectical approach. Cambridge: Cambridge University Press.

Eemeren, Frans H. van \& Peter Houtlosser: 2002a, 'Strategic maneuvering with the burden of proof'. In: F.H. van Eemeren (ed.), Advances in Pragma-Dialectics. Amsterdam: Sic Sat, pp. 13-29.

Eemeren, Frans H. van \& Peter Houtlosser: 2002b, 'Strategic maneuvering in argumentative discourse: a delicate balance'. In: F.H. van Eemeren \& P. Houtlosser (eds.), Dialectic and Rhetoric: The Warp and Woof of Argumentation Analysis. Dordrecht: Kluwer Academic, pp. 131-159. 
Eemeren, Frans H. van, Peter Houtlosser \& A. Francisca Snoeck Henkemans: 2005 forthcoming, 'Dialectical profiles and indicators of argumentative moves'. In: F.H. van Eemeren, M. Hazen, P. Houtlosser \& D. Williams (Eds.) Proceedings of the Wake Forest Conference on Argumentation, Casa Artum, Venice, June 2004. Amsterdam: Sic Sat.

Grootendorst, Rob: 1999, 'Innocence by dissociation. A pragma-dialectic analysis of the fallacy of incorrect dissociation in the Vatican document 'We remember: a reflection on the Shoah'. In: In: F.H. van Eemeren, R. Grootendorst, J.A. Blair, \& Ch.A. Willard (Eds.), Proceedings of the Fourth International Conference of the International Society for the Study of Argumentation. Amsterdam: Sic Sat, pp. 286290.

Naess, Arne: 1966, Communication and Argument. Elements of Applied Semantics. London: Allen \& Unwin.

Perelman, Chaim \& Lucy Olbrechts-Tyteca (1969). The New Rhetoric. A Treatise on Argumentation. Notre Dame/London: University of Notre Dame Press.

Rees, M. Agnès van: 1982, Illocutionaire strekking; betekenis en regels voor gesprekken. Diss. RUL.

Rees, M.Agnès van: 2002, 'Argumentative functions of dissociation in every-day discussions'. In: H.V. Hansen et al. (eds.), Argumentation and its Applications. OSSA'01.

Rees, M.Agnès van: 2003, 'Indicators of dissociation'. In: F.H. van Eemeren e.a. (eds.) Proceedings of the Fifth Conference of the International Society for the Study of Argumentation. Amsterdam: Sic Sat, pp. 887893.

Searle, John R.: 1975, 'Indirect speech acts'. In: P. Cole \& J.L. Morgan (eds.), Syntax and Semantics III: Speech Acts. London: Academic Press, pp. 59-82.

Viskil, Erik: 1994, Definiëren. Een bijdrage tot de theorievorming over het opstellen van definities. Amsterdam: IFOTT.

Zarefsky, David, Frank E. Miller \& Carol Miller-Tutzauer: 1984, 'Reagan's safety net for the truly needy: The rhetorical use of definition'. Central States Speech Journal, 35, 113-119. 